\title{
ULTRASTRUCTURE OF THE AVIAN INTESTINAL MYENTERIC PLEXUS
}

\author{
H. A. ALI \\ ^Faculty of Veterinary Science, University of Khartoum, \\ Khartoum North, P.O.B.32, Sudan \\ Received Fanuary 31, 1984
}

\begin{abstract}
Ali, H. A.: Ultrastructure of the Avian Myenteric Plexus. Acta vet. Brno, 54, 1985: $23-33$.

The fine structure of the myenteric plexus was investigated in 21 male and female White Leghorns aged 4 weeks to 4 months.

Ganglia of the myenteric plexus consisted of a dense neuropil made up of nerve cell bodies, myelinated and unmyelinated axons, Schwann cells and satellite cells. At the periphery of the ganglia was a basal lamina and dense connective tissue containing fibroblasts, interstitial cells and blood vessels. Whilst most of the perikarya were covered by satellite cells, some of them lay directly under the basal lamina. The perikarya displayed the basic structural features of nerve cell bodies. The majority of them had a small number of randomly distributed granular vesicles. Small and large axon profiles were identified. Small axon profiles contained mainly microtubules and neurofilaments, whilst the large (varicose) profiles contained mainly granular and agranular vesicles.

The Schwann and satellite cells were structurally similar. Satellite cells formed membrane specialization with the neurons. The structure of the interstitial cells resembled that of fibroblasts.
\end{abstract}

Fowl, intestines, myenteric plexus, neurons, ganglia, synapses.

Whilst a considerable amount of information is now available on the fine structure of the intestinal myenteric plexuses of mammals (Baumgarten et al. 1970; Gabella 1972; Wong et al. 1974; Cook and Burnstock 1976 a, b) and fish (Wong and Tan 1978), data on the ultrastructure of the avian intestinal myenteric plexus appears to be lacking. However, a few fine structural studies were done on the avian enteric plexuses and these were restricted to the myenteric plexus of the gizzard only (Bennett and Cobb $1969 \mathrm{a}, \mathrm{b}$ ). The aim of this investigation, therefore, is to provide basic information on the fine structure of the avian intestinal myenteric plexus. Such an information can be of great value for understanding and correlating both the physiopharmacological and light microscopic studies carried so far on the avian intestinal myenteric plexus (see Ali and McLelland 1978, 1978, 1980).

\section{Material and Methods}

The fine structure of the myenteric plexus was investigated in 21 male and female White Leghorn domestic fowls ranging in age from 4 weeks to 4 months. Immediately following death small portions of tissue (2-3 mm thick) from the small intestine, rectum and proximal and distal ends of the caeca were rinsed in ice-cold $0.1 \mathrm{M}$ cacodylate buffer ( $\mathrm{pH} 7.4$ ) containing $5 \%$ sucrose and fixed in $2 \%$ osmium tetroxide in veronal acetate buffer $\mathrm{pH} 7.4$ (Palay and Palade 1955) or Karnovsky's (1965) formaldehyde-glutaraldehyde fixative with and without sucrose. Tissues fixed in Karnovsky's fixative were thoroughly washed in cacodylate buffer and postfixed in $2 \%$ osmium tetroxide. Tissue blocks were dehydrated in a graded series of alcohol, cleared in propylene oxide and embedded in araldite. Areas of tissue for examination with the electron microscope 
were chosen from $1-2 \mu \mathrm{m}$ thick sections stained with $1 \%$ toluidine blue or methylene blue. Thin sections were stained with a saturated alcoholic solution of uranyl acetate followed by lead citrate and examined in an AEI EM6B electron microscope.

\section{Results}

\section{Ganglia}

In low power electron micrographs the ganglia consisted of dense neuropil made up of large neurons, nerve bundles, Schwann cells and satellite cells (Fig. 1) The nerve bundles in both the ganglia and the interganglionic parts of the plexus consisted of numerous nonmyelinated nerve fibres $(1.4-2 \mu \mathrm{m}$ in diameter) which were often ensheathed by Schwann cell processes. In the myenteric plexus of the caecum and rectum, however, many myelinated fibres $(1.4-17 \mu \mathrm{m}$ in diameter) were observed (Fig. 2). At the periphery of the ganglia and nerve bundles was a basal lamina, outside of which were collagen fibres and the processes of interstitial cells (Fig. 3). Most neurons appeared to be completely covered with satellite cells (Fig. 1) and their processes (Fig. 3). In some neurons, however, part of the plasma membrane lay directly under the basal lamina (Fig. 4). Collagen fibres frequently penetrated into the ganglia (Fig. 5) although they remained outside the basal lamina.

\section{Neurons}

The nerve cell bodies varied widely in shape and size. Generally, however, they were elongate or spherical, the perikaryon ranging in length from 15 to $25 \mu \mathrm{m}$ and in width from 6 to $10 \mu \mathrm{m}$. The nucleus was usually large and round, oval or elongate with an irregular indented outline (Fig. 6). The electronlucent karyoplasm consisted of euchromatin, clumps of heterochromatin being only occasionally observed.

Structural differences occurred among the neurons of the plexus. However, because of the limitations of thin sections, it was found difficult to classify the neurons into different types.

Characteristically the cytoplasm contained many ribosomes. These were either attached to the flat stacks, short cisternae and vesicles of the prominent rough endoplasmic reticulum or randomly distributed as ribosomal rosettes (Fig. 7). A few profiles of smooth endoplasmic reticulum were frequently encountered. The extensive Golgi complex (Fig. 8) was usually perinuclear, although Golgi profiles were also seen in the large processes of some neurons. The profiles consisted of flattened, occasionally fenestrated cisternae, small electronlucent vesicles and coated vesicles. A large number of small round or elongate mitochondria were generally evenly distributed throughout the perikaryon of the majority of neurons (Fig. 9). Within the mitochondria the transverse cristae were embedded in a dense granular matrix. Multivesicular bodies were frequently seen among the ribosomal rosettes.

A few granular vesicles $(70-100 \mu \mathrm{m}$ in diameter) occurred in the majority of the neurons (Fig. 10, 11). The vesicles generally appeared to be randomly scattered throughout the cytoplasm although sometimes they were concentrated in the region of the Golgi complex (Fig. 11). Other cytoplasmic contents included numerous microtubules and neurofilaments (Fig. 12) and lysosome-like bodies (Fig. 10, 11).

\section{Neuronal processes}

Most of the neurons had several processes extending from the perikaryon into the surrounding neuropil (Figs. 13, 14, 15, 16). The majority of the processes were 
covered with the processes of satellite and Schwann cells, a few being covered with only a basal lamina (Fig. 16). The processes varied widely in shape, size, structure and electron density. It was not possible to distinguish the origin of axons from those of other processes. The cytoplasm of most processes contained varying quantities of ribosomes, rough endoplasmic reticulum, mitochondria, microtubules, smooth endoplasmic reticulum, lysosome-like bodies and occasionally Golgi profiles.

Non-neuronal cells

The non-neuronal cells in the plexus greatly outnumbered the nerve cell bodies and included Schwann cells, satellite cells and the so-called "interstitial cells" or fibroblast-like cells.

\section{Schwann and satellite cells}

Schwann cells occurred in both the ganglia and the interganglionic nerve bundles and had many processes which ensheathed axons (Fig. 1, 17). A basal lamina completely enveloped the Schwann cell and its processes and the outer surface of the satellite cell.

Satellite cells lay entirely within the ganglia in direct association with the nerve cell bodies, often appearing to sit on a depression on the surface of the neuron (Figs. 1, 18). The gap between the satellite cell and the neuron was about $20 \mu \mathrm{m}$.

Structurally the Schwann and satellite cells were similar. The nucleus was smaller than that of the neurons and it was generally oval, crescent-shaped or spherical and deeply indented (Fig. 17). In both cell types the heterochromatin was extremely prominent and was usually distributed as clumps attached to the inner surface of the nuclear membrane (Fig. 17). The cytoplasmic contents included a well developed perinuclear Golgi complex, rough endoplasmic reticulum, many ribosomes, ribosomal rosettes, microtubules, filaments, centrioles, a few lysosome-like bodies and numerous mitochondria. Filamentous structures were a characteristic feature of Schwann cell processes.

Specializations of cell membranes were not observed between adjacent processes of Schwann cells or between the processes and axons. Membrane specialization between the processes of satellite cells and neurons frequently occurred (Fig. 19). A gap of about $20-27 \mu \mathrm{m}$ separated the apposed plasma membranes. The membrane specializations were in the form of either symmetrical localized dersities beneath the apposed plasma membranes of the satellite cell process and the neuron or only the plasma membrane of the satellite cell process.

\section{Interstitial cells}

These fibroblast-like cells occurred in the connective tissue surrounding the ganglia and the interganglionic nerve bundles (Figs. 20,21). A basal lamina was never seen around these cells. The interstitial cells varied widely in shape and size. The elongate, oval or round nucleus had an irregular indented outline and prominent heterochromatin. The cytoplasmic contents were typical of fibroblast cells. The cytoplasm extended into irregular processes. These processes contained a few mitochondria, ribosomes and lysosome-like bodies.

Axon profiles

Two types of axon profile were observed. Many profiles were relatively small $(0.3 \mu \mathrm{m}$ in diameter) and contained many microtubules and filaments (Fig. 22). The 
other axon profile was varicose (more than $0.3 \mu \mathrm{m}$ in diameter) and contained numerous vesicles (Fig. 23). These varicosities were specially common within the ganglia.

The vesicles within the varicosities were of two sorts, dense-cored or granular vesicles and agranular vesicles which varied in proportion to each other (Fig. 23). The granular vesicles constituted a heterogenous population made up of small (40-60 $\mathrm{nm}$ in diameter), medium (70-90 $\mathrm{nm}$ in diameter) and large $(90-160 \mathrm{~nm}$ in diameter) vesicles. In the majority of the vesicles the central core was markedly electron dense and clearly separated from the limitirg membrare by a distinct halo about $10 \mathrm{~nm}$ wide. Other vesicles had an indistinct core (Fig. 22). The agranular vesicles appeared to be uniform in size $(40-70 \mathrm{~nm}$ in diameter).

According to the size and type of vesicles present in each axonal swelling, three groups of varicosities were indentified:

1. These varicosities ranged from $0.3-0.5 \mu \mathrm{m}$ in diameter ard contained numerous agranular vesicles and a few medium-sized granular vesicles (Fig. 24); varicosities containing only agranular vesicles were occasionally observed (Fig. 25).

2. Some varicosities were about $0.6 \mu \mathrm{m}$ in diameter and contained numerous agranular vesicles and a few small granular vesicles (Fig. 26).

3. The third type of varicosity was about $1.5 \mu \mathrm{m}$ in diameter and contained numerous agranular vesicles, many large granular vesicles and a few small granular vesicles (Fig. 27).

\section{Synapses}

Differentiation of membranes of many varicosities which was characteristic of synapses was observed (Figs. 24, 26, 27). These synapses occurred with both perikarya and dendrites, the axodendritic synapse appearing to be much more numerous. All types of varicosities described above formed synapses. Frequently, different types of varicosities were observed to synapse with the same neuron (Fig. 25). Occasionally a single varicosity was seen to have more than ore synapse with a neuron (Fig. 27). The presynaptic membrane thickening of the axon was always less developed than the post-synaptic membrane thickenirg of the neuron. The synaptic cleft was approximately $20-25 \mathrm{~nm}$ wide and contained a material of medium electron density. A continuous layer of dense material, the subsynaptic web, usually projected from the postsynaptic membrane into the neuron for a distance of $40-50 \mathrm{~nm}$ (Figs. 24, 27). A similar dense material was also associated with the pre-synaptic membrane. Usually many vesicles were tightly packed below the presynaptic membrane. These vesicles were generally agranular (Figs. 24, 27) and only rarely were granular vesicles seen in this position (Fig. 26). No vesicles were associated with the postsynaptic membrane.

\section{Discussion}

The present study appears to be the first investigation of the ultrastructure of the intestinal myenteric plexus of birds. As in vertebrates the avian myenteric plexus appeared as a loose tangle of neural and non-neural elements covered externally by a fibrous capsule. This capsule extended into the plexus partially dividing it into compartments. Whilst such a division was not observed in mammals, a similar subdivision has been described by Wong and Tan (1978) in the stomach of the Coral fish (Chelmon rostratus). As suggested by these authors, the collagen septa in the avian myenteric plexus may also act to prevent interaction between groups of neurons and axons. If this is true, then the absence of these septa in the mammalian plexus would be difficult to understand. 
The blood capillaries associated with the avian intestinal myenteric plexus were never observed to penetrate inside the neuropil. A similar relationship between blood vessels and nervous tissue was found in mammals by Gabella (1972). In the stomach of the coral fish, however, Wong and Tan (1978) reported the presence of capillaries within the neuropil. This suggests at first sight that the neural elements in the fish have a more ready access to oxygenated blcod. However, in both birds and mammals (Richardson 1960; Taxi 1965; Gabella 1972) but not apparently in fish, many perikarya and their processes are situated at the surface of the garglia directly below the basal lamina. In this position the neural elements will be able to carry out their nutritional exchange with the periganglionic blood capillaries. Certainly in mammals, as noted by Gabella (1972) the myenteric plexus must be well supplied with blood since the experiments of Canon and Burket (1913) and Welsh and Hyde (1944) indicate that it is very resistent to anoxia. Similar experiments, unfortunately, have not been made in birds.

In the intestinal myenteric plexus of birds the majority of the axons were unmyelinated, although myelinated axons were observed. Both types of axons were described in the gizzard (Bennett and Cobb 1969 b). In mammals (Gabella 1972; Cook and Burnstock 1976 a, b) only unmyelinated axons have been observed. Although Wong and Tan (1978) found myelinated axons in the fish stomach, on the basis of their own unpublished observations with the electron microscope and evidence obtained with the light microscope by T an ard Teh. (1974), they concluded that myelinated axons do not extend distal to the stomach. Ur.forturately, information on the occurrence of myelinated axons in the intestines of the different classes of vertebrates is not available. However, the presence of myelinated axons in fish and birds and their absence in mammals, would suggest that they may possibly be an evolutionary feature, but further studies are required to establish this.

The present observations on the fine structure of the perikarya agree in general with the findings in other classes of vertebrates. Whilst many differences in detailed structure were certainly present between the perikarya in birds, it was not possible to formulate in single sections a reliable procedure for classifying neurons. Previous attempts to classify the enteric neurons at the electron microscope level (Fehér and Csányi 1974; Cook and Burnstock 1976 a) have been based on single or semiserial sections and large numbers of electron micrographs and relied mainly on the size of the perikaryon and the intracytoplasmic distribution of the organelles. The fact that the plane of sectioning can alter the size and structure of neurons may explain why Fehér and Csányi (1974) identified three types of cell whereas Cook and Burnst o ck (1976 a) identified nine cells. Furthermore, structural differences between neurons in the degree of development of the endoplasmic reticulum, the Golgi areas, and in the presence or absence of granular vesicles may possibly indicate functional variation.

Recent studies with silver impregnation methods on the avian myenteric plexus revealed five types of cells (Ali 1979). Of these type I, II and III argyrophilic neurons corresponded to those described by Dogiel $(1896,1898)$ using the methylene blue stain. Whilst Dogiel's classification has been repeatedly confirmed, it is not universally accepted (see Ali 1979). The main criticism apparently being the recognition of a number of intermediate types of neurons and argyrophobic neurons. The general conclusion, therefore, reached by recent investigations on the enteric neurons seems to be that no clear cut classification exists. Despite this, the electrophysiological studies of Hirst et al. (1974) and Wood (1974) have established the existence of different types of enteric neurons in mammals, and an early objective should be to identify these neurons from their structure. Linking the present observations with 
the appearance of the neurons under the light microscope would be a step in this direction, but unfortunately no correlation has emerged.

An interesting feature of the myenteric perikarya in birds is that they contained a small number of granular vesicles up to $60 \mathrm{~nm}$ in diameter. Although most of the vesicles were randomly distributed throughout the cytoplasm, some of them appeared to be closely associated with the cisternae of the Golgi complex. This close association suggests that the Golgi complex may be involved in their synthesis. Perikarya containing granular vesicles of similar size have also been observed in the rat intestine (Oosaki 1970) and guinea pig stomach (Cook and Burnstock 1976 a). Oosaki and Sugai (1974) have suggested that these granular cells were responsible for the perikaryonal fluorescence which they observed in their study. However, none of the perikarya in the avian intestinal myenteric plexus (Ali and McLelland 1978) was fluorescent which would seem to indicate that the granular cells in rats need not necessarily be adrenergic.

In the present investigation many terminal axons were identified. Those were distinguished by their large size and content of vesicles. According to the type of the vesicles three sorts of terminal profiles were described. The first type contained a predominance of agranular vesicles. Similar profiles have been described in both birds (Bennett at al. 1974) and mammals (Baumgarten et al. 1970) and are generally considered as cholinergic. The second profile contained small granular vesicles and varying numbers of agranular vesicles. This profile fulfils the criteria for adrenergic axons (Grillo and Palay 1962; Baumgarten et al. 1970; Gabella 1972; Burnstock and Costa 1975; Cook and Burnstock 1976 a). The third type of varicosity contained numerous agranular vesicles and large granular vesicles and a few small granular vesicles. Similar profiles have been described in the gut of mammals by Baumgarten et al. (1970); Gabella (1972) and Cook and Burnstock (1970 a) although their function has not been established. According to Baumgarten et al. (1970), these profiles belong to p-type neurons and are identical to the axons of the myenteric plexus demonstrated by Gershon and Ross (1966) to take up labelled 5-hydroxytryptamine. However, Gabella (1972) pointed out that the existence of tryptaminergic neurons in the myenteric plexus is still controversial. Another possibility is that the third type of varicosity is adrenergic since the majority of non-cholinergic varicosities which have been described in various adrenergically innervated avian tissues contained predominantly large granular vesicles. Furthermore, Bennett et al. (1970) have shown that small doses of 6-hydroxydopamine preferentially loaded the large granular vesicles, the effect being blocked by reserpine which is known to deplete tissue catecholamines.

All types of axon profiles identified in the present study made direct contact with the neurons forming typical efferent synapses (Gabella $1971 \mathrm{a}$ ). In these the plasma membrane of the axon was presynaptic and was generally associated with clusters of agranular vesicles, whilst the plasma membrane of the neuron was postsynaptic and markedly thickened compared to the presynaptic membrane. At all levels of the gut the synapses appeared to be numerous (unlike, for example, in fish (Wong and Than 1978) and this may suggest the existence of a high degree of integrative activity. No axon profiles were observed in the present study which contained large numbers of mitochondria and therefore, similar to suggested sensory endings (Burnstock and Iwayama 1971; King et al. 1974).

The principal non-neuronal cells observed in the present investigation included Schwann cells, satellite cells and interstitial cells. The structure of the cells associated with the neurons (satellite cells) and those associated with axons (Schwann cells) was essentially similar and conformed to the descriptions in other vertebrates as 
described by Ba umgarten et al. (1970); Gabella (1971, 1972); Wong (1973); Cook and Burnstock (1976 b) and Wong and Tan (1978). However, the cell membrane specialization between the satellite cells and the perikarya do not appear to have been described before. In contrast to the mammalian enteric plexuses ( $\mathrm{Ga}$ bella 1972; Cook and Burnstock 1976 b) desmososome-like structures were not observed to be associated with the Schwann cells. Although the nature of the interstitial cells of Cajal (1911) have been the subject of much controversy (see Roger and Burnstock 1966), it is now almost universally accepted that they are structurally similar to fibroblasts.

\section{Acknowledgements}

The author would like to thank the British Council and the University of Khartoum for financial support.

\section{Ultrastruktura plexus myentericus u kura domácího}

Na 21 kohoutcích a kuřičkách White Leghorn ve věku 4 týdnů až 4 měsíců byla studována ultrastruktura plexus myentericus.

Ganglia plexus myentericus sestávají $\mathrm{z}$ elektronově densního neuropilu tvořeného těly nervových buněk, myelinizovaných i nemyelinizovaných axonů, Schwannových a satelitních buněk. Na periferii ganglií je lamina basalis a pojivová tkáň obsahující fibroblasty, intersticiální buňky a krevní cévy. Většina neurocytů je kryta satelitními buňkami, některé přiléhají prŕímo pod lamina basalis. Většina jich obsahuje granulární váčky. Byly identifikovány malé a velké průřezy malými a velkými axony. Malé axony obsahují zejména mikrotubuly a neurofilamenta, velké (varikózní) obsahují granulární a agranulární vesikuly. Schwannovy a satelitní buňky jsou si strukturálně podobny. Satelitní buňky tvoři s neurony membránové specializované útvary. Intersticiální buňky strukturou připomínají fibroblasty.

\section{Ульстраструктура межмышечного сплетения у домашней курицы}

На 21 петушке и молодках White Leghorn в возрасте 4 недель - 4 месяца проводились исследования ультрастуктуры межмышечного сплетения.

Ганглии межмышечного сплетения состоят из электронно денсионного нейропила, состоящего из тел нервных клеток, миелинизированных аксонов, клеток Шванна и сателлитных клеток. На периферии ганглий находится основная пластинка и соединительная ткань, содержащая фибробласты, интерстициальные клетки и кровеносные сосуды. Большинство нейроцитов покрыто сателлитными клетками, прилагающими прымо из-под основной пластинки. Большинство из них содержит гранулярные мешочки. Были установлены маленькие и большие сечения малыми и большими аксонами. Малые аксоны содержат в особенности микротрубочки и нейрофиламенты, большие (варикозные) содержат гранулярные и агранулярные везикулы. Клетки Шванна и сателлитные клетки структурного похожи. Сателлитные клетки вместе с нейронами образуют мембранные специализированные формации. Интерстициальные клетки по своей структуре напоминают фибробласты. 


\section{References}

ALI, H. A.: Light microscopic and ultrastructural studies on the enteric nerve plexuses of the domestic fowl. Ph. D thesis, University of Edinburgh, 1979.

ALI, H. A. - McLELLAND, J.: Avian enteric nerve plexuses. A histochemical study. Cell Tiss. Res., 189, 1978: 537.

ALI, H. A. - McLELLAND, J.: Neuron number in the intestinal myenteric plexus of the domestic fowl (Gallus gallus) Zbl. Vet. Med. C. Anat. Histol. Embryol. Berlin (west), Hamburg, 8, 1979: 277.

ALI, H. A. - McLELLAND, J.: Variations in neuron size in the avian intestinal myenteric plexus. Anat. Anz., 147, 1980: 348.

BAUMGARTEN, H. G. - HOLSTEIN, A. F. - OMAN, C. H.: Aeurbach's plexus of mammals and man: electron microscopic identification of three different types of neuronal processes in myenteric ganglia of the large intestine from rhesus monkeys, guinea pigs and man. Z. Zellforsch., 106, 1970: 376.

BENNETT, T. - BURNSTOCK, T. G. - COBB, J. L. - MALMFORS, T.: An ultrastructural and histochemical study of the short term effects of 6-hydroxydopamine on adrenergic nerves in the domestic fowl. Br. J. pharmac., London 38, 1970: 802.

BENNETT, T. - COBB, J. L.: Studies on the avian gizzard: morphology and innervation of the smooth muscle. Z. zellforsch., 96, 1969 a: 173.

BENNETT, T. -- COBB, J. L.: Studies on the avian gizzard: Auerbach's plexus. Z.Z ellforsch, 99, 1969 b: 109.

BENNETT, T. - COBB, J. L. - MALMFORS, T.: The vasomotor innervation of the inferior vena cava of the domestic fowl (Gallus gallus domesticus). 1. structural observations. Cell Tiss. Res., 148, 1974: 521.

BURNSTOCK, G. - COSTA, M.: Adrenergic neurons: their organization, function and development in the peripheral nervous system. Chapman and Hall, London 1975.

BURNSTOCK, G. - IWAYAMA, T.: Fine structural identification of autonomic nerves and their relation to smooth muscle. Prog. Brain Res., 54, 1971: 389.

CAJAL, S. R.: Histologie du système nerveux de l'homme et des vertebres. Ed. by A. MaLUINE, Paris 1911.

CANON, W. B. - BURKET, L. R.: The endurance of anaemia by nerve cells in the myenteric plexus. Amer. J. Physiol. 32, 1913: 347.

COOK, A. D. - BURNSTOCK, G.: The ultrastructure of Auerbach's plexus in the guinea pig. 1. Neuronal elements. J. Neurocytol., 5, 1976 a: 171.

COOK, R. D. - BURNSTOCK, G.: The ultrastructure of Auerbach's plexus in the guinea pig. 11. Non - neuronal elements. J. Neurocytol., 5, 1976 b: 195.

DOGIEL, A. S.: Zwei Arten sympathischer Nervezellen. Anat. Anz., 11, 1896: 699.

DOGIEL, A. S.: Úber den Ban Ganglion in den Geflechten des Darmes un der Gallenblase des Menschen und der Saugetiere. Arch. Anat. Physiol., Anat. Abst. 1898: 130-158.

FEHÉR, E. - CSÁNYI, K.: Ultra-architectonics of the neural plexus in the chronically isolated small intestine. Acta anat., 90, 1974: 617.

GABELLA, G.: Synapses of adrenergic neurons. Experientia, 27, 1971: 280.

GABELLA, G.: Fine structure of the myenteric plexus in the guinea pig ileum. J. Anat., III, 1972: 69.

GERSHON, M. D. - ROSS, L. L.: Location of sites of 5-hydroxytryptamine storage and metabolism by radioautography. J. physiol., 186, 1966: 477.

GRILLO, M. - PALAY, L.: Granule-containing vesicles in the autonomic nervous system. In: 5th international Congress of Electron microscopy, Vol. 2, p. U-1. Ed. by S. S. Breese. Academic press. Philadelphia and New York 1962.

HIRST, D. G. S. - HOLMAN, M. E. - SPENCE, I.: Two types of neurons in the myenteric plexus of duodenum in the guinea pig. J. Physiol. (London), 236, 1974: 303.

KARNOVSKY, M. J.: A formaldehyde-glutaraldehyde fixative of high osmolarity for use in electron microscopy. J. Cell Biol., 27, 1965: 137 a.

KING, A. S. - McLELLAND, J. - KING, D. Z. - WALSH, C.: The ultrastructure of afferent nerve endings in the avian lung. Res. physiol., 22, 1974: 21.

OOSAKI, T.: A granular vesicle-containing ganglion cell in Auerbach's plexus of the rat small intestine. Fukushima J. Med. Sci., 17, 1970: 41.

OOSAKI, T. - SUGAI, N.: Morphology of extraganglionic fluorescent neurons in the myenteric plexus of the small intestine of the rat. J. comp. Neurol., 158, 1974: 109.

PALAY, S. L. - PALADE, G. E.: The fine structure of neurons. J. biophys. biochem. Cytol., 1, 1955: 69.

RICHARDSON, K. C.: Studies on the structure of autonomic nerves in the small intestine, 
correlating the silver-impregnated image in light microscopy with the permanganate-fixed ultrastructure in electron microscopy J. Anat., 94, 1960: 457.

TAN, C. K. - TEH, Y. F.: The structure of the gut of a coral fish Chelmon rostratus cuvier. Okajimas folia anat. Jap., 51, 1974: 63.

TAXI, J.: Contribution a l'etude des connexions des neurones moteurs du systeme nerveux autonomic. Ann. Sci. anat., 7, 1965: 413.

WELSH, J. H. - HYDE, J. E.: Acetylcholine content in the myenteric plexus and resistance to anoxia. Proc. Soc. exp. Biol. Med., 55, 1944: 256.

WONG, W. C.: The myenteric plexus in the oesophagus of the toad (Bufo melanosticus). Acta anat., 85, 1971: 52.

WONG, W. C. - HELME, R. D. - SMITH, G. G.: Degeneration of noradrenergic nerve terminals in the submucous ganglia of rat duodenum following treatment with 6-hydroxydepamine. Experintia, 30, 1974: 282.

WONG, W. C. - TAN, C. K.: Fine structure of the myenteric and submucous plexuses in the stomach of the coral fish (Chelmon rostratus cuvier) J. Anat., 126, 1978: 291.

WOOD, J. D.: Neurophysiology of ganglia of Auerbach's plexus. Am zool., 14, 1974: 973.

Legends to figures:

Fig. 1

A low-power micrograph of a ganglion in the myenteric plexus of the rectum showing a large neuron (N), small elongate satellite cells $(\mathrm{Sa}) \S$ Schwann cell (sc.) At the periphery of the ganglion is a basal lamina (arrows) outside of which are collagen fibres and fibroblast-like cells. C, collagen fibres; $\mathrm{Sm}$, smooth muscle cell; $\mathrm{v}$, varicose axon. $\times 5,500$.

Fig. 2

Myenteric plexus of the rectum showing myelinated fibres. The fibres contain numerous microtubules and filaments, outside the Schwann cell processes and the basal lamina are collagen fibres (C) and interstitial cells (1). × 12,000.

Fig. 3

The external surface of the neuron $(\mathrm{N})$ is covered completely with an irregular satellite cell process (Sa). Outside the satellite cell process is a basal-lamina (arrows). Collagen fibres (C) and the processes of fibroblast-like cells $(F) . \times 15,500$.

Fig. 4

The nerve cell body $(\mathrm{N})$ is incompletely covered with the satellite cell process $(\mathrm{Sa})$. The rest of the plasma membrane lies directly under the basal lamina (arrows). Sc, Schwann cell process. $\times 16,500$.

Fig. 5

A ganglion from the myenteric plexus of the ileum. Connective tissue septa $(S)$ extend from the outer connective tissue layer $(C)$ into the ganglion. $N$, nerve, cell body. $\times 21,000$.

Fig. 6

The large nucleus of the neuron $(\mathrm{N})$ has an irregular indented outline. Prominent nucleoli (n) are present in the electronlucent karyoplasm. The karyoplasm consists only of euchromatin. $\times 18,000$.

Fig. 7

Cytoplasm of a myenteric neuron showing a well-developed rough endoplasmic reticulum (rer) and many ribosomes arranged as rosettes. $\times 37,000$.

Fig. 8

A nerve cell body showing extensive perinuclear Golgi areas (G): The areas consist of flattened occasionally fenestrated cisternae and electronlucent vesicles. Nuc, nucleus; rer, rough endoplasmic reticulum; $\mathrm{m}$, mitochondria. $\times 19,000$.

Fig. 9

Cytoplasm of a neuron showing mitochondria the cristae are embedded in a dense granular matrix. $\times 20,000$.

Fig. 10

Cytoplasm of a neuron showing many randomly distributed granular vesicles. A few of these vesicles (arrows) occur near the Golgi area (G). Ly, lysosome-like body; m, mitochondria.

$\times 26,000$.

Fig. 11

Cytoplasm of a neuron showing granular vesicles close to a well developed Golgi area (G). Ly, lysosome-like body; r, ribosomes. $\times 23,000$.

Fig. 12

Cytoplasm of a neuron showing microtubules (mt) and neurofilaments. r, ribosomes; $\mathrm{m}$, mitochondria. $\times 39,000$. 
Fig. 13

A finger-like process $(\mathrm{P})$ emerges from the nerve cell body $(\mathrm{N})$ by a narrow origin. The cytoplasm of the process is of low or medium electron density and has ribosomes, a few stacks of rough endoplasmic reticulum and lysosome-like bodies. C, collagen fibres; a, axons. $\times 20,000$.

Fig. 14

A broad process (P) extends from the nerve cell body $(\mathrm{N})$. The process is relatively electron-dense and the cytoplasm contains Golgi areas, ribosomes, rough endoplasmic reticulum and lysosome-like bodies. Note the small process (arrow) coming from the broad neuronal process. ta, terminal axons. $\times 15,000$.

Fig. 15

A broad and electron-dense process $(\mathrm{P})$ of a nerve cell body $(\mathrm{N})$. Part of the process is covered with a basal-lamina (arrows). Sa, Satellite cell; a, axons; V, varicosity. $\times 14,000$.

Fig. 16

The short filiform process $(P)$ has a narrow origin from the nerve cell body $(N)$ and lies directly under the basal-lamina (arrow). Note that the cytoplasm of the process is of a medium or low electron-density and contains few organelles. $\times 17,500$.

Fig. 17

The oval nucleus (Nuc) of the Schwann cell (Sc) is deeply indented and has prominent heterochromatin attached to the inner surface of the nuclear membrane. The cytoplasm extends into numerous processes $(P)$ which ensheath axons. A basal lamina (arrows) surrounds the Schwann cell and its processes. The cytoplasm of the Schwann cell contains perinculear Golgi areas and mitochondria. $\mathrm{O}$, connective tissue; $\mathrm{Nm}$, nonmyelinated fibres. $\times 21,000$.

Fig. 18

The satellite cell ( $\mathrm{Sa}$ ) appears to sit in a depression on the surface of the neuron $(\mathrm{N})$ the surface of the satellite cell furtherest from the neuron is covered with a basal lamina (arrow). The cytoplasm contains ribosomes, perinuclear Golgi area (G), multivesicular body, (mv) centriole (c) and mitochondria $(\mathrm{m}) . \times 16,500$.

Fig. 19

Membrane specializations are shown between the plasma membranes of the satellite cell process

(Sa) and the neuron (N). C, connective tissue; Ly, lysosome-like body; m, mitochondria. $\times 17,000$.

Fig. 20

The spherical nucleus of the interstitial cells (1) has an irregular indented outline and prominent heterochromatin attached to the nuclear membrane. The cytoplasm contains a few stacks of rough endoplasmic reticulum, ribosomes, Golgi areas (G), coated vesicles, mitochondria, microtubules and lysosome-like bodies. $P$, process of interstitial cell. $\times 15,600$.

Fig. 21

Several interstitial cell processes (P) and numerous collagen fibres (C) are shown at the periphery of the myenteric ganglion. $\mathrm{N}$, nerve cell body; Sa, Satellite cell process. $\times 16,000$

Fig. 22

Non-varicose axons (a) containing microtubules and neurofilaments. $\times 25,000$.

Fig. 23

A varicose axon (V) showing numerous agranular and granular vesicles and several mitochondria. Whilst small and large granular vesicles occur in the varicosity, the agranular vesicles appear to be uniform in size. In the majority of the granular vesicles the central dense core is separated from the limiting membrane by a distinct clear zone. $\times 26,000$.

Fig. 24

Group 1 varicosity $(\mathrm{V})$ synapsing with a nerve cell process $(\mathrm{P})$. The varicosity contains numerous agranular vesicles and a few medium-sized granular vesicles. The core of some of the vesicles is indistinct. A dense subsynaptic web adheres to the entire inner surface of the thickened postsynaptic membrane of the nerve cell process. In contrast the presynaptic membrane of the axon is less thickened and a similar dense material is attached at one en (arrow). Agranular vesicles only are tightly packed below the presynaptic membrane. $\times 60,000$.

Fig. 25

Two varicosities, one containing agranular vesicles (Vl) and the other agranular and small granular vesicles (V2) synapse with the same neuron $(\mathrm{N})$. V, varicose axons. $\times 16,500$. 

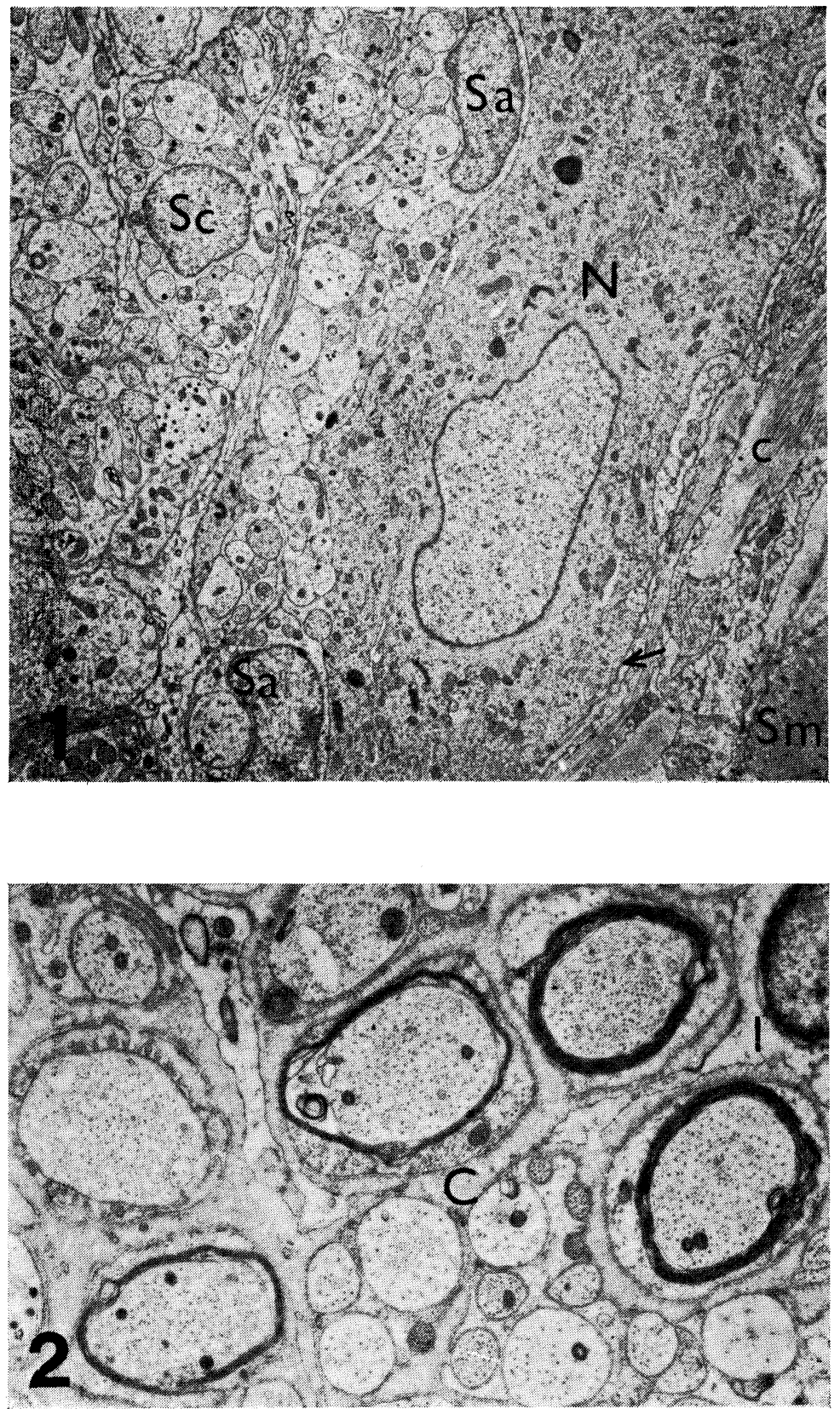

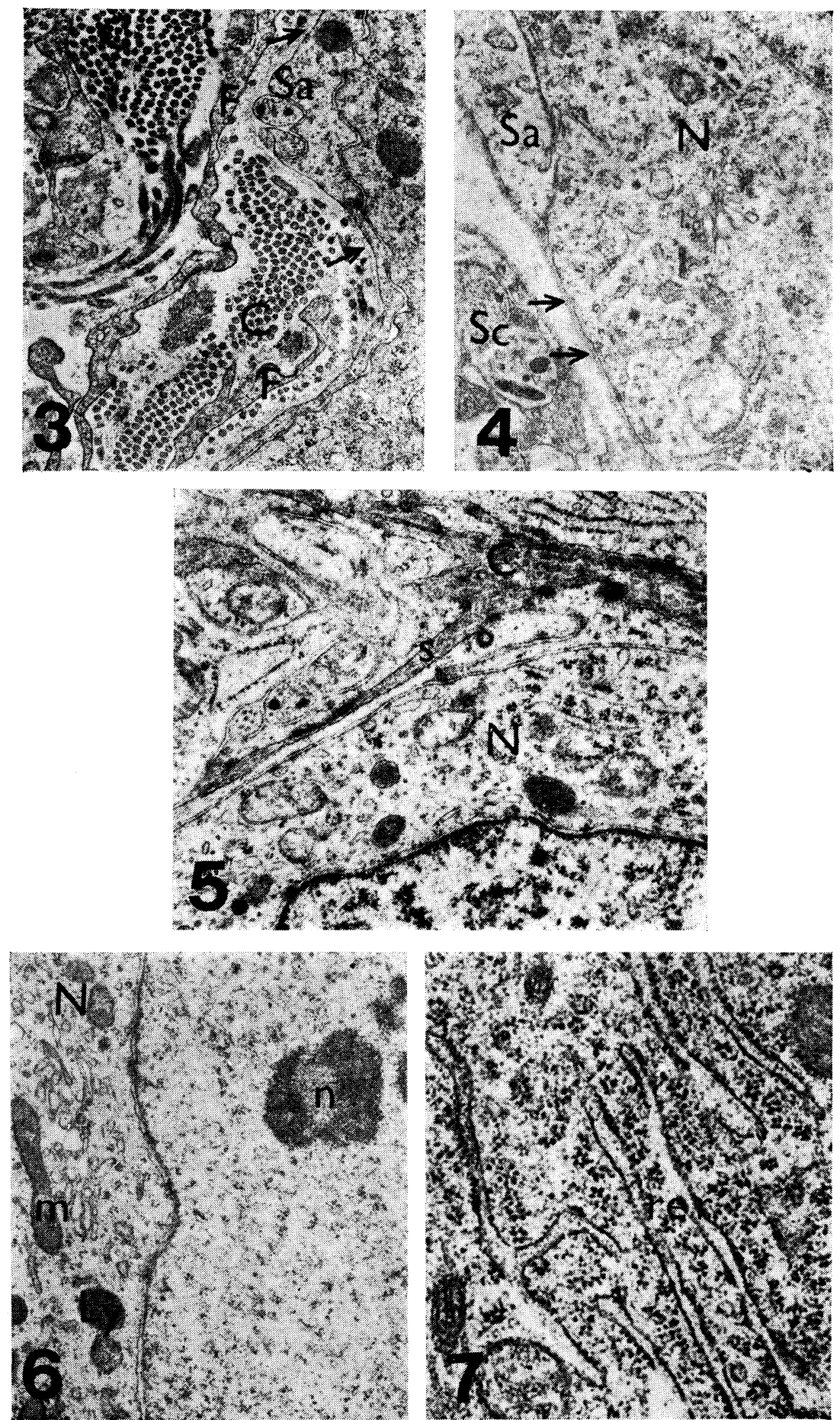

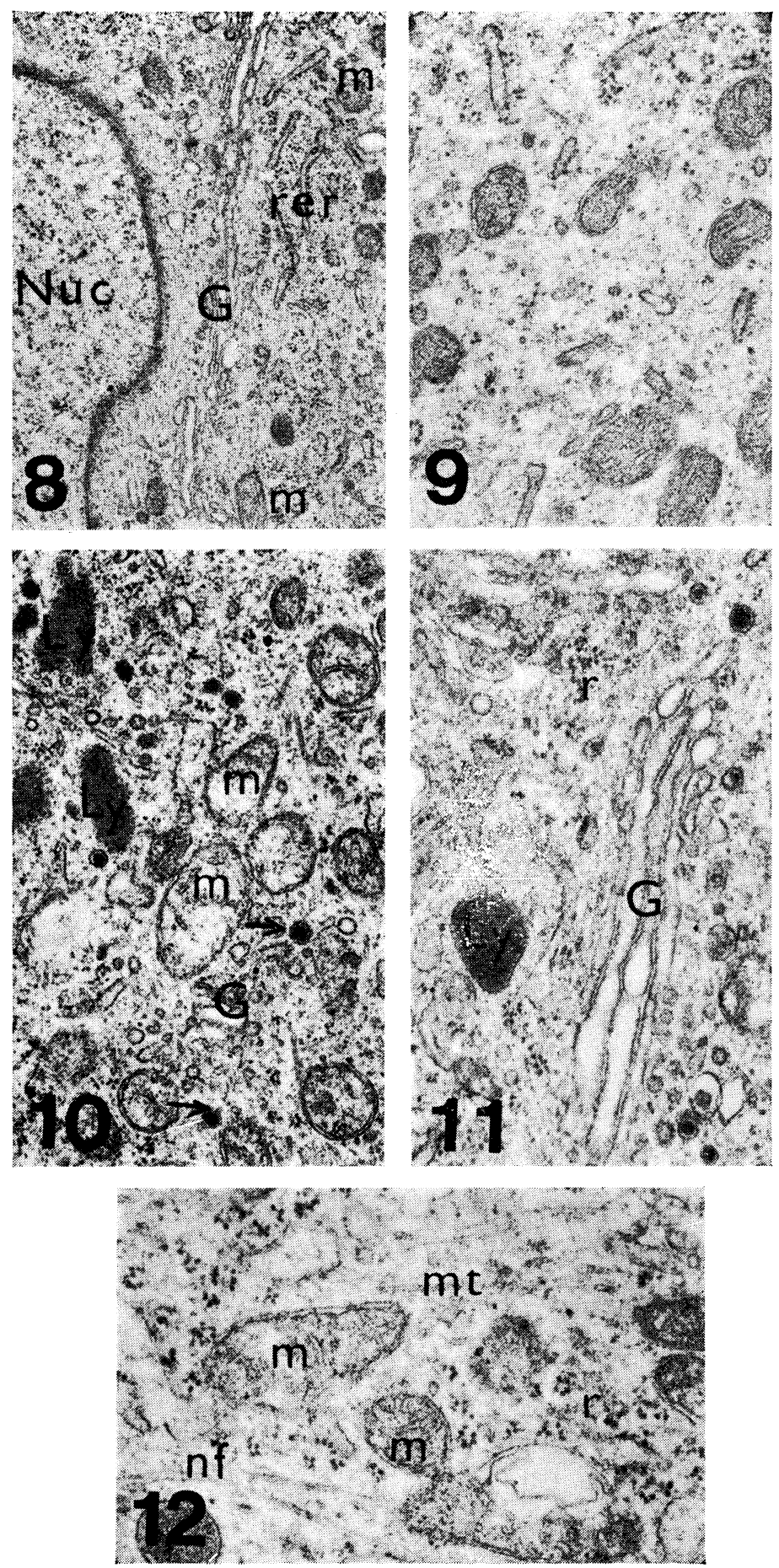


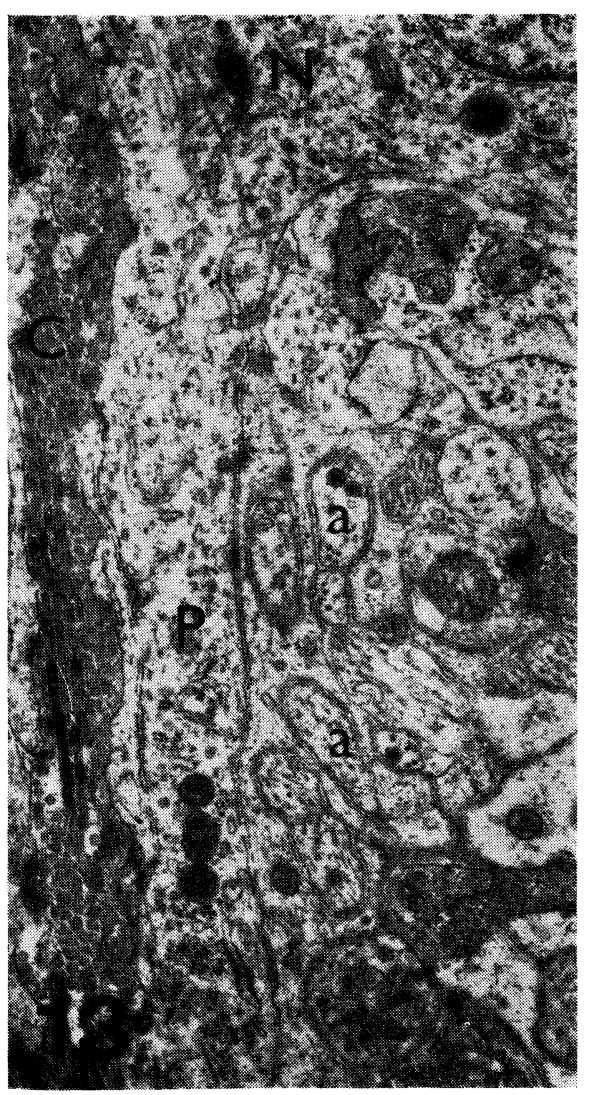
No. sols

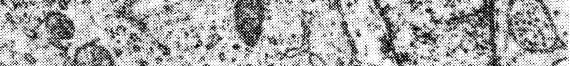
19. (5. (ove.:. $x-360+10$ a $\quad \times 5 \%$ a $-129+2$ (.) s. 3.0.

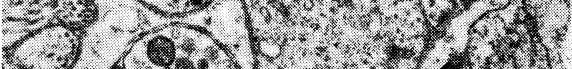
. (1) . 150.2. $15.2-2 \times 4+2$

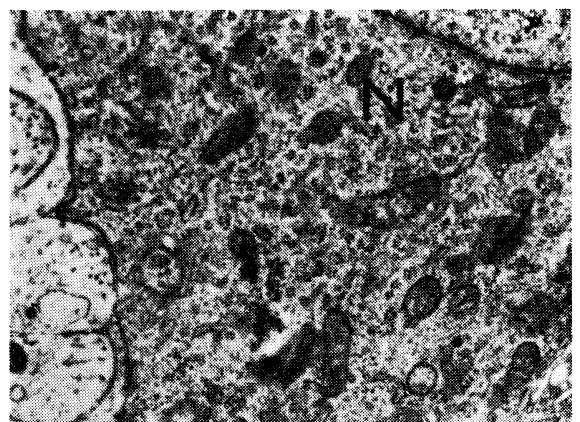

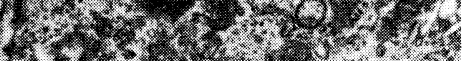

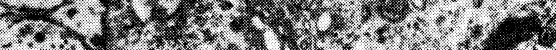

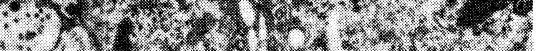

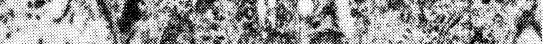

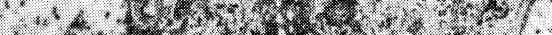

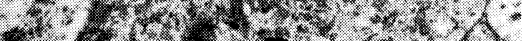

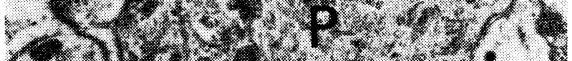

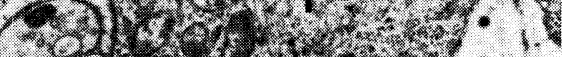

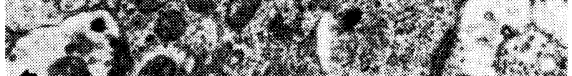

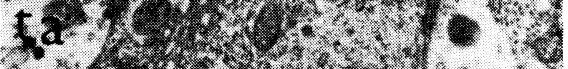
(a)

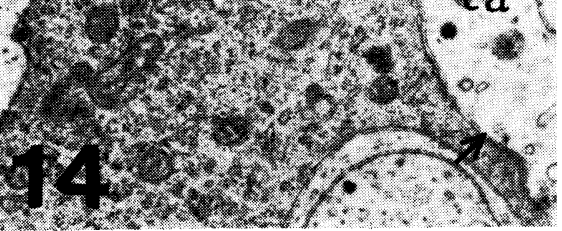

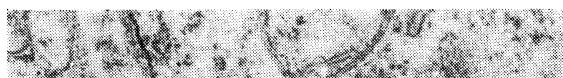

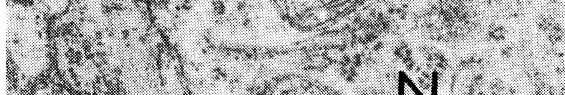

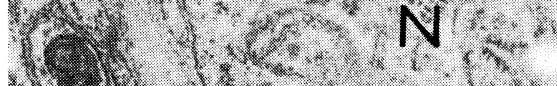

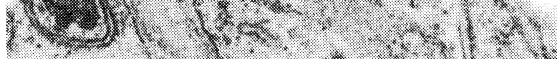

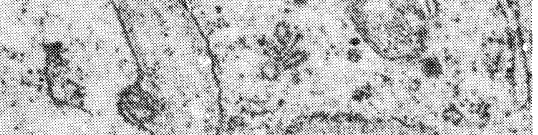

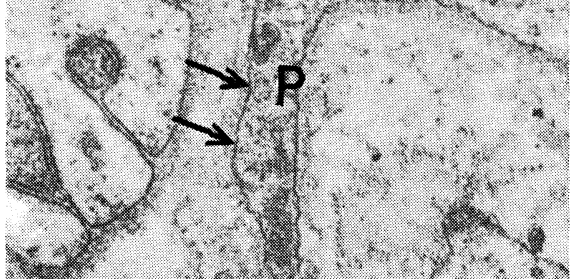

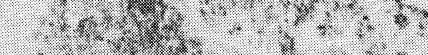
$16+x-3,3$ 

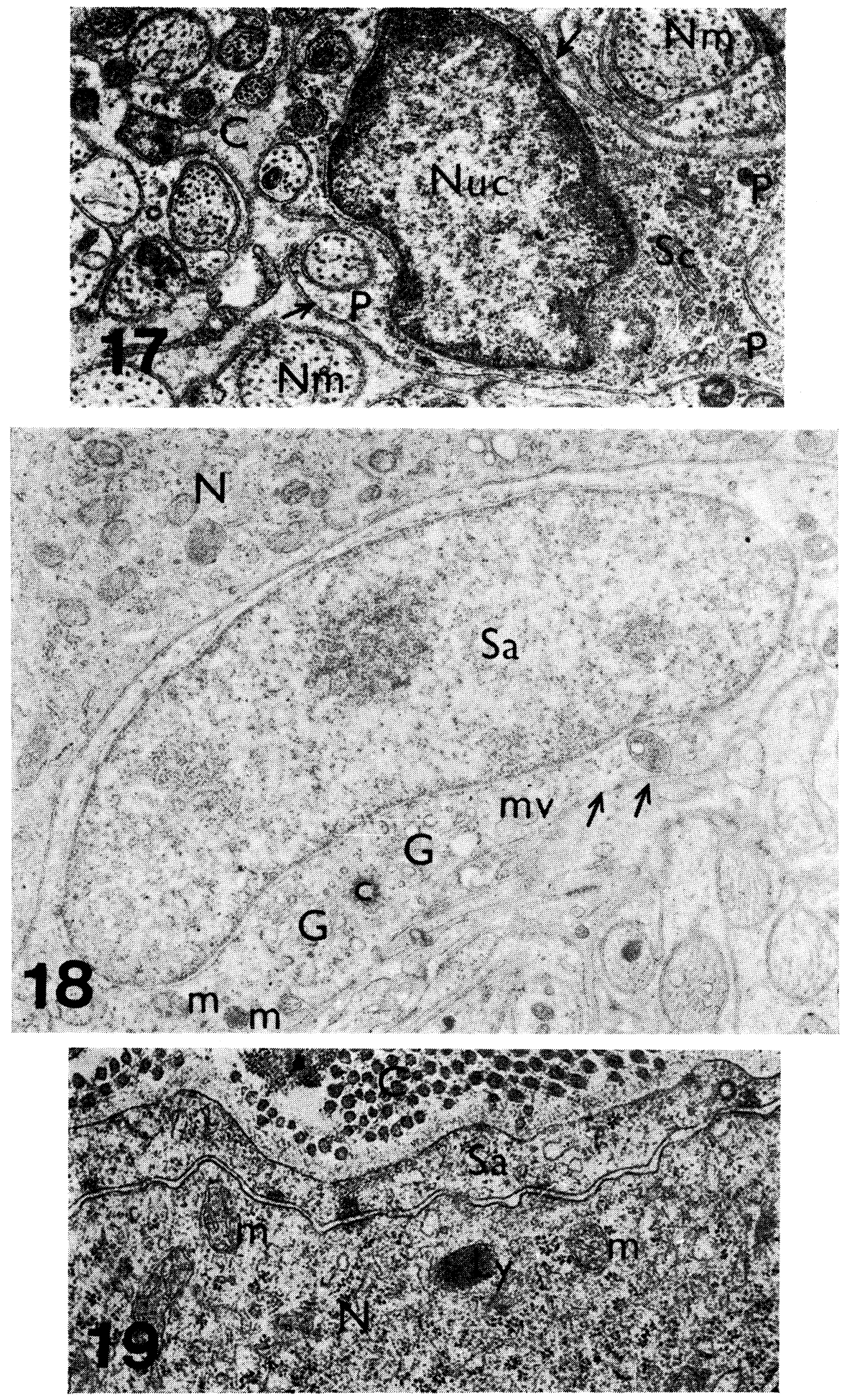

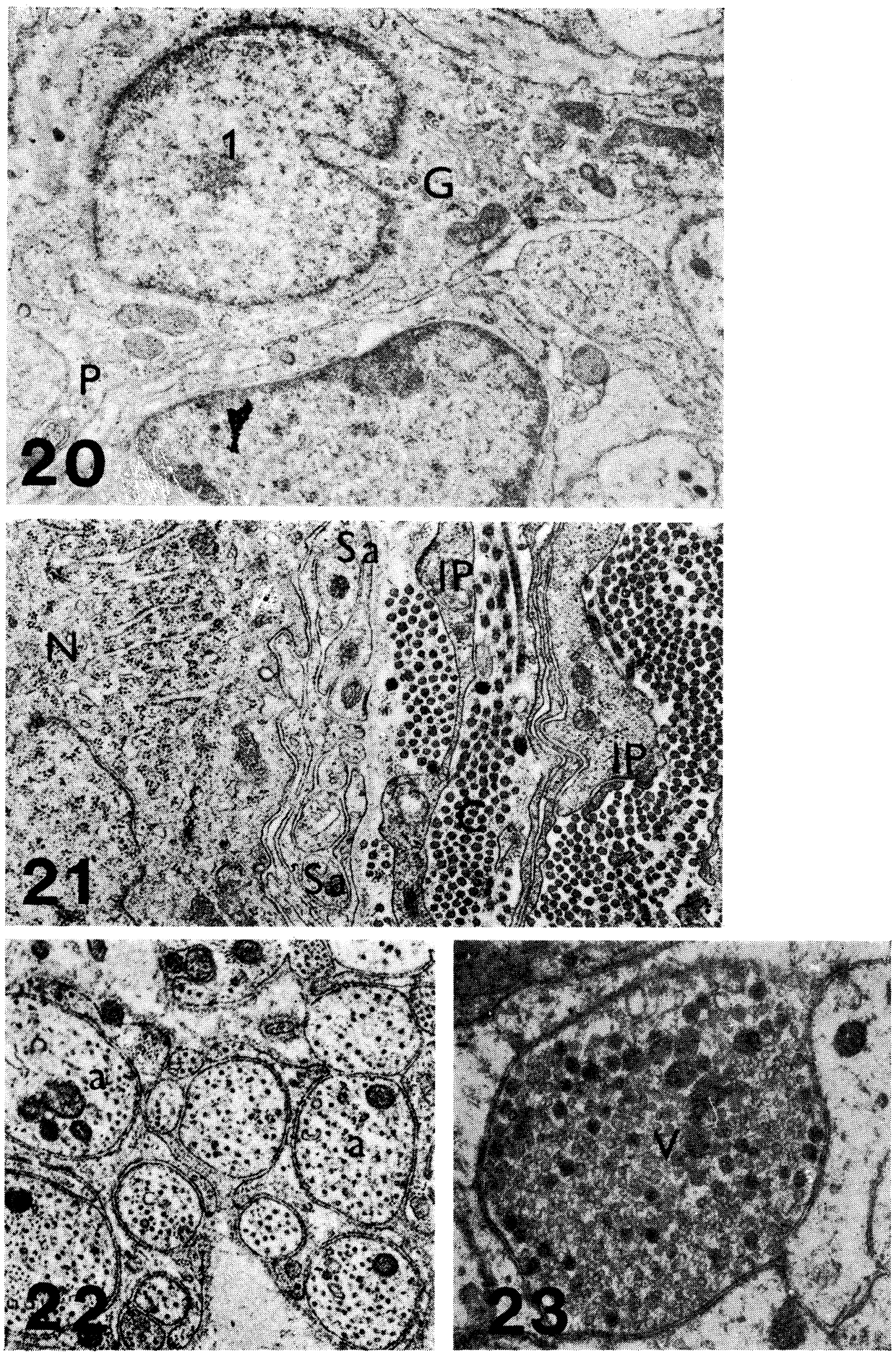

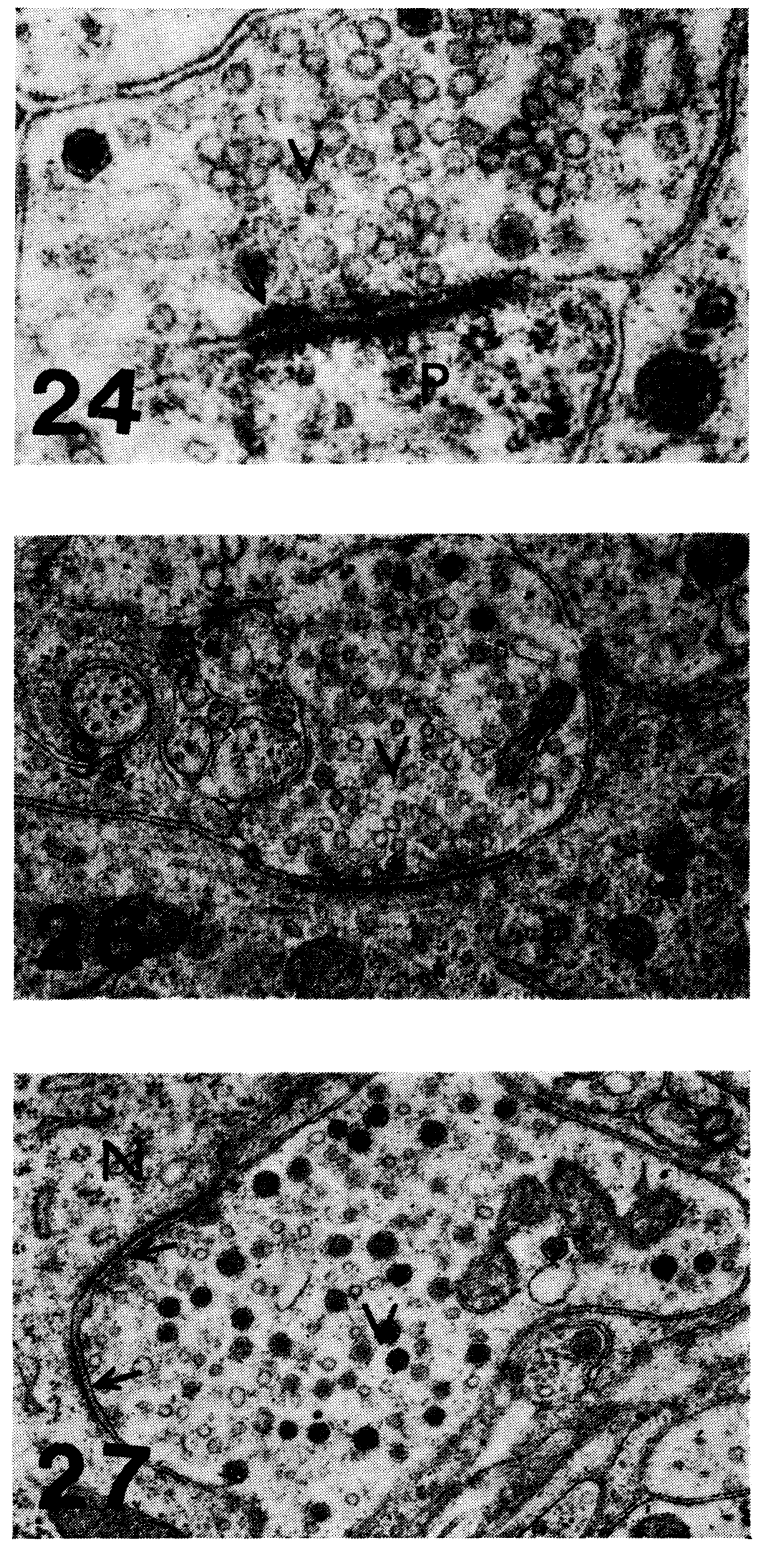

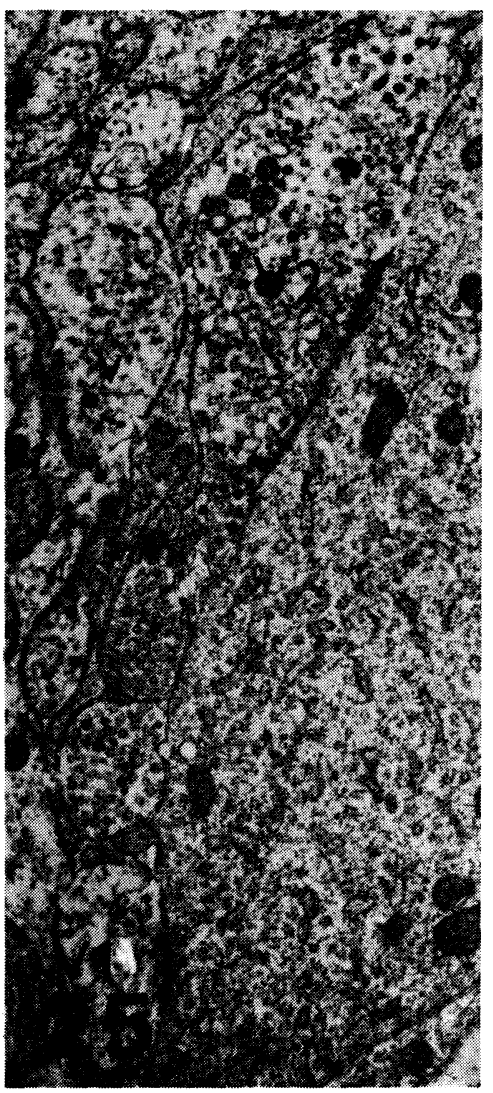


Fig. 26

Group 2 varicosity $(V)$ synapsing with a nerve cell process $(P)$. The varicosity contains numerous agranular vesicles and a few small granular vesicles. A dense material is associated with both the postsynaptic and presynaptic membranes. Note the granular ves. situated just below the presynaptic membrane. Sa, satellite cell process. $\times 25,000$.

\section{Fig. 27}

Group 3 varicosity $(\mathrm{V})$ synapsing with the neuron $(\mathrm{N})$. The varicosity contains numerous agranular vesicles, many large granular vesicles and a few small granular vesicles. In some of the granular vesicles the core is indistinct. The varicosity synapses with the neuron at two points (arrows). Between the two synapses the intercellular gap widens. A dense material only projects from the postsynaptic membrane. $\times 28,000$.

\footnotetext{
* Present address:

Department of Anatomy

Faculty of Veterinary Medicine

ElFateh University

Tripoli P. O. Box 13662, Libya
} 